\title{
PEMBENTUKAN DAN PELATIHAN KADER POSYANDU BALITA DI BANJAR BULUH DESA GUWANG KECAMATAN SUKAWATI KABUPATEN GIANYAR
}

\author{
Krisnayani, Ni Made Wina ${ }^{1 *}$; Putra, I Gede Yudiana ${ }^{1}$; Dewi, Ni Luh Made Asri ${ }^{1}$ \\ ${ }^{1}$ Akademi Keperawatan Kesdam IX/Udayana \\ *Korespondensi: Winakrisna86@gmail.com
}

\begin{abstract}
Background: Pos Pelayanan Terpadu or Posyandu are Post of Integrated Service. Posyandu were an effort to empower the community to support health development, especially in improving community health status through reducing infant mortality. Posyandu activities in Guwang Sukawati Gianyar village are one of the public health services. However, each banjar is still very minimal in terms of organizing the posyandu because the cadres do not really understand how the activities of the good posyandu. The purpose of this activity is to establish a Posyandu cadre of toddlers who are able to provide optimal health services for children under five through the implementation of a toddler posyandu. Method: Training was carried out through Community Empowering, involving 35 people who were trained as cadres. The training results are analyzed qualitatively (based on observations and results of discussion). Results: Based on the evaluation in the form of pretest and posttest, it was found that there was an increase in cadre knowledge, namely from $30 \%$ to $70 \%$. Posyandu has been conducted in 7 Banjar in the Guwang Gianyar Village. Conclusion: The establishment of skilled and trained Posyandu toddlers and able to provide optimal health services for children under five through the implementation of toddlers posyandu
\end{abstract}

Keywords: cadres; posyandu; toddler

\begin{abstract}
ABSTRAK
Latar Belakang: Pos Pelayanan Terpadu (Posyandu) merupakan upaya pemberdayaan masyarakat untuk menunjang pembangunan kesehatan, khususnya dalam meningkatkan derajat kesehatan masyarakat melalui penurunan angka kematian bayi. Kegiatan posyandu di desa Guwang Sukawati Gianyar merupakan salah satu pelayanan kesehatan masyarakat. Tetapi masing-masing banjar masih sangat minim dalam hal penyelenggaraan posyandu karena para kader kurang begitu memahami bagaimana kegiatan posyandu baik mengenai cara pelaksanaan maupun mengenai posyandu itu sendiri. Tujuan kegiatan ini adalah untuk membentuk kader posyandu balita yang mampu memberikan pelayanan kesehatan secara optimal pada balita melalui pelaksanaan posyandu balita. Metode: Pelatihan dilaksanakan melalui Community Empowering, melibatkan 35 orang yang dilatih sebagai kader. Hasil pelatihan
\end{abstract}


dianalisis secara kualitatif (berdasarkan observasi dan hasil diskusi). Hasil: Berdasarkan evaluasi berupa pretest dan postest diketahui bahwa terjadi peningkatan pengetahuan kader yaitu dari 30\% menjadi 70\%. Telah dilaksanakan posyandu dilaksanakan di 7 banjar di wilayah Desa Guwang Gianyar. Simpulan: Terbentuknya kader posyandu balita yang terlatih dan terampil, serta mampu memberikan pelayanan kesehatan secara optimal pada balita melalui pelaksanaan posyandu balita.

Kata kunci: kader; posyandu; balita

\section{PENDAHULUAN}

Dengan berkembangnya Pembangunan Kesehatan Masyarakat Desa (PKMD) dan dalam implementasinya menggunakan pendekatan edukatif, munculah berbagai kegiatan swadaya masyarakat untuk pelayanan kesehatan antara lain: Pos Penimbangan Balita, Pos Imunisasi, Pos KB Desa, Pos Kesehatan, Dana Sehat. Selain itu juga muncul berbagai kegiatan lain, yang berada di luar kesehatan, meskipun tetap ada kaitannya dengan bidang kesehatan. Kegiatan-kegiatan tersebut murni muncul dari masyarakat sendiri, dan untuk pelayanan mereka sendiri, dibidang kesehatan.

Secara teori, pada periode ini telah muncul perbedaan sudut pandang. Mulai terlihat bahwa salah satu kelemahan dari pendekatan edukatif adalah belum berhasil memunculkan “community real need”. Yang terjadi adalah bahwa melalui pendekatan edukatif ini telah muncul berbagai “community felt need”. Akibatnya muncul berbagai kegiatan masyarakat sesuai kebutuhan masyarakat tersebut. Dengan munculnya aneka ragam kegiatan masyarakat tersebut, sulit untuk memperhitungkan kontribusi kegiatan masyarakat tersebut terhadap peningkatan derajat kesehatan masyarakat. Hal ini mendorong para pengambil keputusan di lingkungan Departemen Kesehatan untuk melakukan perubahan pada pendekatan edukatif sebagai strategi pemberdayaan masyarakat dalam pembangunan kesehatan. Berdasarkan pemikiran tersebut, maka pada tahun 1984, berbagai kelompok kegiatan yang berkaitan dengan pelayanan kesehatan (Pos Penimbangan Balita, Pos Imunisasi, Pos KB Desa, Pos Kesehatan), dilebur menjadi satu bentuk pelayanan kesehatan terpadu yang disebut Posyandu (pos pelayanan terpadu). Atau lengkapnya Pos Pelayanan Terpadu KB-Kesehatan. 
Peleburan menjadi Posyandu tersebut, selain dicoba dikembangkan di Jawa Timur, juga setelah melalui tahap kegiatan uji coba di tiga provinsi, yaitu: Sumatera Selatan, Jawa Barat dan Sulawesi Selatan. Dipadukannya pelayanan KB dan kesehatan ini dimaksudkan untuk memberikan kemudahan dan keuntungan bagi masyarakat. Karena dengan keterpaduan pelayanan ini masyarakat dapat memperoleh pelayanan lengkap pada waktu dan tempat yang sama. Kegiatan posyandu di desa Guwang Sukawati Gianyar merupakan salah satu pelayanan kesehatan masyarakat. Tetapi masing-masing banjar masih sangat minim dalam hal penyelenggaraan posyandu karena para kader kurang begitu memahami bagaimana kegiatan posyandu baik mengenai cara pelaksanaan maupun mengenai posyandu itu sendiri. Maka dari itu, peneliti tertarik untuk mengetahui tingkat pengetahuan para kader kesehatan mengenai kegiatan posyandu. Secara konseptual, Posyandu merupakan bentuk modifikasi yang lebih maju dalam upaya pemberdayaan masyarakat untuk menunjang pembangunan kesehatan, khususnya dalam rangka meningkatkan derajat kesehatan masyarakat melalui penurunan angka kematian bayi. Modifikasi tersebut adalah dengan tetap mempertahankan prinsip dari, oleh dan untuk masyarakat, gotong royong dan sukarela, namun bentuk kegiatan masyarakat dalam pembangunan kesehatan tidak lagi beragam, karena sudah diarahkan dan diseragamkan yaitu Posyandu.

Melalui keseragaman kegiatan masyarakat dalam bentuk Posyandu, diharapkan dapat berdampak pada peningkatan derajat kesehatan masyarakat, khususnya penurunan angka kematian bayi dan balita. Posyandu merupakan unit pelayanan kesehatan di lapangan yang diselenggarakan oleh masyarakat untuk masyarakat dengan dukungan teknis Puskesmas, Departemen Agama, Departemen Pertanian, dan BKKBN. Posyandu melaksanakan 5 program kesehatan dasar yakni: KB, kesehatan ibu dan anak, gizi, imunisasi, dan penaggulangan diare.

Adapun sasaran utama adalah menurunkan angka kematian bayi dan memperbaiki status kesehatan dan gizi balita, maupun ibu hamil dan menyusui. Posyandu merupakan wadah partsipasi masyarakat, karena Posyandu paling banyak menggunakan tenaga kader. Kader ini merupakan tenaga relawan murni, tanpa dibayar, namun merupakan tenaga inti di Posyandu. Sebagian besar kader adalah wanita, 
anggota PKK (Pembinaan Kesejahteraan Keluarga). Maka dapat dikatakan bahwa PKK merupakan sumber penggerak Posyandu. Kegiatan posyandu di desa Guwang Sukawati Gianyar merupakan salah satu pelayanan kesehatan masyarakat. Tetapi masing-masing banjar masih sangat minim dalam hal penyelenggaraan posyandu karena para kader kurang begitu memahami bagaimana kegiatan posyandu baik mengenai cara pelaksanaan maupun mengenai posyandu itu sendiri.

Maka dari itu, pengabdi tertarik untuk mengetahui tingkat pengetahuan para kader kesehatan mengenai kegiatan posyandu. Kegiatan di posyandu merupakan kegiatan nyata yang melibatkan partisipasi masyarakat dalam upaya pelayanan kesehatan dari masyarakat, oleh masyarakat dan untuk masyarakat, yang dilaksanakan oleh kader-kader kesehatan yang telah mendapatkan pendidikan dan pelatihan dari puskesmas mengenai pelayanan dasar.

\section{METODE}

Kegiatan ini dilaksanakan melalui pendekatan Pemberdayaan Masyarakat (Community Empowering), dengan memberdayakan masyarakat sebagai kader. Dengan metode ceramah, diskusi, tanya jawab, simulasi pembentukan posyandu dan pelatihan kader posyandu balita, simulasi 5 meja. Pelatihan dilaksanakan di Banjar Buluh Desa Guwang Kecamatan Sukawati Gianyar tanggal 5 s.d 15 April 2015. Pelaksanaan posyandu dilaksanakan di 7 banjar Desa Guwang Gianyar. Analisis data dilakukan dengan pendekatan kualitatif. Pendekatan kualitatif yang dilakukan yaitu dengan menganalisis data hasil diskusi dan observasi peserta pelatihan dengan mengikuti jalannya pelatihan.

\section{HASIL DAN PEMBAHASAN}

Secara konseptual, Posyandu merupakan bentuk modifikasi yang lebih maju dalam upaya pemberdayaan masyarakat untuk menunjang pembangunan kesehatan, khususnya dalam rangka meningkatkan derajat kesehatan masyarakat melalui

penurunan angka kematian bayi. Modifikasi tersebut adalah dengan tetap mempertahankan prinsip dari, oleh dan untuk masyarakat, gotong royong dan sukarela, 
namun bentuk kegiatan masyarakat dalam pembangunan kesehatan tidak lagi beragam, karena sudah diarahkan dan diseragamkan yaitu Posyandu. Melalui keseragaman kegiatan masyarakat dalam bentuk Posyandu, diharapkan dapat berdampak pada peningkatan derajat kesehatan masyarakat, khususnya penurunan angka kematian bayi dan balita. Dari hasil pelatihan dari masing-masing banjar yaitu pada tanggal 5 April 2015, dilaksanakan pelatihan kader posyandu balita di Wantilan Desa Guwang. Pelatihan kader Posyandu balita tersebut dilakukan oleh pihak Team dari Akper Kesdam IX/Udayana, mahasiswa dan bekerja sama dengan Puskesmas. Pelatihan kader posyandu balita tersebut dihadiri oleh kader posyandu balita yang sudah terpilih dari masing-masing banjar yaitu Banjar Sakih 5 orang, Banjar Dangin Jalan 5 orang, Banjar Tagtag 5 orang, Banjar Buluh 5 orang, Banjar Tegal 5 orang, Banjar Manikan 5 orang dan Banjar Wangbung 5 orang. Pada saat pelakasnaan pelatihan kader posyandu para kader diberikan materi terlebih dahulu oleh team dari Akper Kesdam IX/Udayana kemudian diberikan simulasi 5 meja oleh pihak puskesmas.

Tabel 3. Tabel Rekap Pelatihan Kader Posyandu Balita Di Wantilan Desa Guwang

\begin{tabular}{|c|c|c|c|c|}
\hline NO & NAMA BANJAR & $\begin{array}{c}\text { JADWAL } \\
\text { PELAKSANAAN }\end{array}$ & $\begin{array}{c}\text { JUMLAH SELURUH } \\
\text { BALITA }\end{array}$ & $\begin{array}{c}\text { JUMLAH } \\
\text { BALITA YANG } \\
\text { HADIR } \\
\end{array}$ \\
\hline 1 & Banjar Sakih & $\begin{array}{c}6 \text { April } 2015 \\
(08.00-11.00 \text { Wita })\end{array}$ & 79 orang & 43 orang \\
\hline 2 & Banjar Dangin Jalan & $\begin{array}{c}7 \text { April } 2015 \\
\text { (08.00-11.00 Wita) }\end{array}$ & 45 orang & 27 orang \\
\hline 3 & Banjar Tagtag & $\begin{array}{c}8 \text { April } 2015 \\
(08.00-11.00 \text { Wita })\end{array}$ & 15 orang & 13 orang \\
\hline 4 & Banjar Buluh & $\begin{array}{c}9 \text { April } 2015 \\
\text { (08.00-11.00 Wita) }\end{array}$ & 84 orang & 31 orang \\
\hline 5 & Banjar Tegal & $\begin{array}{c}13 \text { April } 2015 \\
\text { (08.00-11.00 Wita) }\end{array}$ & 24 orang & 18 orang \\
\hline 6 & Banjar Manikan & $\begin{array}{c}14 \text { April } 2015 \\
\text { (08.00-11.00 Wita) }\end{array}$ & 46 orang & 21 orang \\
\hline 7 & Banjar Wangbung & $\begin{array}{c}15 \text { April } 2015 \\
\text { (08.00-11.00 Wita) }\end{array}$ & 53 orang & 17 orang \\
\hline
\end{tabular}

Pada tanggal 6 April 2015 dilaksanakan Posyandu Balita di Banjar Sakih. Jumlah balita 79 orang sedangkan balita yang hadir dalam posyandu sebanyak 43 orang. Posyandu balita dilaksanakan pada pukul 08.00-11.00 Wita. Pada tanggal 7 
April 2015 dilaksanakan di Banjar Dangin Jalan. Jumlah balita sebanyak 45 orang sedangkan yang hadir 27 orang. Pada tanggal 8 April 2015 dilaksanakan di Banjar Tagtag dengan jumlah balita sebanyak 15 orang sedangkan yang hadir 13 orang yang dilaksanakan pukul 08.00-10.30. Pada tanggal 9 April 2015 di banjar Buluh dengan jumlah balita sebanyak 84 orang sedangkan yang hadir 31 orang yang dilaksanakan pukul 08.00-11.00. Pada tanggal 13 April 2015 dilakaksanakan di Banjar Tegal sebanyak 24 orang balita dan dihadiri 18 orang balita pada pukul 08.00-11.00. Pada tanggal 14 April 2015 dilaksanakan di Banjar Manikan sebanyak 46 orang balita sedangkan peserta yang hadir 21 orang pada pukul 08.00-11.00. Pada tanggal 15 April 2015 di banjar Wangbung, jumlah balita sebanyak 53 orang sedangkan yang hadir sebanyak 17 orang.

\section{SIMPULAN}

Berdasarkan pelaksanaan kegiatan pengabdian masyarakat Akper Kesdam IX/Udayana yaitu pre planning pembentukan dan pelatihan kader posyandu balita di Banjar Buluh Desa Guwang Kecamatan Sukawati Kabupaten Gianyar. Dapat diuraikan beberapa kesimpulan. Kegiatan pelatihan kader posyandu balita dirasakan banyak memberi manfaat bagi kader-kader posyandu. Kegiatan dilaksanakan dengan metode penyampaian materi serta pelatihan, simulasi dan diskusi yang kondusif. Hasil dari proses pelatihan para peserta mengerti tentang pelaksanaan kegiatan posyandu balita yang benar sesuai dengan 5 meja. Pelatihan kader posyandu berpengaruh terhadap peningkatan kemampuan dalam memberikan pelayanan kesehatan secara optimal pada balita melalui pelaksanaan posyandu balita.

\section{DAFTAR PUSTAKA}

Adi, Heru S.2005. Kader Kesehatan Masyarakat.Jakarta: EGC.Penerbit Buku Kedokteran Arikunto,S.2002.Prosedur Penelitian Suatu Pendekatan Praktek. Jakarta: Rineka Cipta Depkes,RI.2008.Buku Kesehatan Ibu dan Anak Gerakan Pemantauan Tumbuh Kembang Anak.Jakarta: Depkes RI 
Depkes,RI 2006. Buku Kader Posyandu Dalam Upaya Perbaikan Gizi Keluarga. Jakarta: Depkes RI

Notoatmojo,S.2003.Pendidikan dan Perilaku Kesehatan.Jakarta:Rineka Cipta.

Nursalam.2001. Metode Riset Keperawatan.CV Information:Jakarta

Rahayu,Budi. 2006. Buku Pegangan Kader Posyandu.Surabaya:Dikes Provinsi Jawa Timur Soetjiningsih.1995.Tumbuh Kembang Anak. Jakarta: EGC Jakarta 